\title{
2 A EFETIVIDADE DA \\ COLABORAÇÃO E O \\ RESULTADO ÚTIL DO \\ PROCESSO NOS ACORDOS DE LENIÊNCIA ANTITRUSTE
}

\author{
The effectiveness of collaboration and the \\ useful result of the process in antitrust leniency \\ agreements
}

Waldir Alves ${ }^{1}$

Natalie Giacomazzi Viccari²

\section{RESUMO}

O artigo aborda questões relacionadas ao relevante papel exercido pelo Tribunal Administrativo do Cade no controle formal e material dos acordos de leniência antitruste, tendo como base o conteúdo da efetividade da colaboração e o resultado útil do processo. Parte da definição de acordo de leniência, identifica suas fases e pontua as características do Programa de Leniência Antitruste do Cade. Aponta que a perspectiva de um programa de leniência calcado na justa concessão dos benefícios premiais pelo Estado está condicionada ao adimplemento de obrigações assumidas pelo signatário, sem, contudo, descuidar-se dos resultados legais indicados pela norma, tendo como centro a ideia de eficácia e utilidade da colaboração, a partir de critérios legais objetivos. Nesse cenário, é traçado um paralelo com o acordo de colaboração premiada, cuja experiência brasileira está avançada no Judiciário, inclusive nas Instâncias Superiores. Aborda a competência exclusiva do Tribunal Administrativo do Cade na análise da declaração de cumprimento ou de descumprimento dos acordos de leniência e o controle de sua eficácia. Por fim, analisa as consequências e os efeitos do descumprimento de acordo de leniência por parte do signatário no caso de ausência de cooperação e menciona importantes julgados proferidos pelo Tribunal Administrativo do Cade.

Palavras-chave: acordo de leniência; antitruste; colaboração; efetividade; descumprimento; controle de eficácia; Tribunal Administrativo do Cade.

1 Procurador Regional da República. Representante Titular do Ministério Público Federal - MPF junto ao Conselho Administrativo de Defesa Econômica - Cade. Membro Suplente da 3a Câmara de Coordenação e Revisão do Ministério Público Federal (Ordem Econômica e Consumidor). Doutor em Direito do Estado e Teoria do Direito pela Universidade Federal do Rio Grande do Sul - UFRGS. Especialista em Direito Tributário pela Fundação Universidade Regional de Blumenau - FURB. Professor da Escola Superior do Ministério Público da União - ESMPU. E-mail: alveswaldir@hotmail.com

2 Analista Jurídica Concursada do Ministério Público Federal. Assessora Jurídica do Representante Titular do Ministério Público Federal junto ao Conselho Administrativo de Defesa Econômica - MPF/Cade. Especialista em Ciências Criminais pela Universidade do Sul de Santa Catarina - UNISUL. Pós-graduanda em Defesa da Concorrência e Direito Econômico pela Fundação Getúlio Vargas - FGV. E-mail: natalie.giacomazzi@gmail.com 


\section{ABSTRACT}

The article addresses issues related to the relevant role played by CADE's Administrative Court in the formal and material control of antitrust leniency agreements, based on the content of the effectiveness of the collaboration and the useful result of the process. Part of the definition of a leniency agreement, it identifies its phases and points out the characteristics of CADE's Antitrust Leniency Program. It points out that the perspective of a leniency program based on the fair granting of premium benefits by the State is conditioned to the fulfillment of obligations assumed by the signatory, without, however, neglecting the legal results indicated by the standard, having as its center the idea of effectiveness and usefulness of collaboration, based on objective legal criteria. In this scenario, a parallel is drawn with the award-winning collaboration agreement, whose Brazilian experience is advanced in the Judiciary, including the Superior Courts. It addresses the exclusive competence of the Administrative Court of CADE in analyzing the declaration of compliance or noncompliance with leniency agreements and the control of their effectiveness. Finally, it analyzes the consequences and effects of non-compliance with the leniency agreement by the signatory in the event of lack of cooperation and mentions important judgments handed down by the Administrative Court of CADE.

Keywords: leniency agreement; antitrust; collaboration; effectiveness; non-compliance; effectiveness control; CADE Administrative Court.

Classificação JEL: K21 e L40

Sumário: 1. Considerações iniciais; 2. Aspectos formais do acordo de leniência antitruste; 3. A efetividade da ação colaborativa; 4 . 0 resultado útil do processo; 5. Breve paralelo com a esfera penal; 6. 0 Tribunal Administrativo do Cade e o controle de eficácia do acordo de leniência antitruste; 7. Descumprimento do acordo de leniência antitruste e as consequências advindas; 8. Casuística; 9. Considerações finais; 10. Referência bibliográfica.

\section{INTRODUÇÃO}

Os sofisticados e complexos ilícitos, principalmente as novas modalidades de arranjos colusivos, aliados às dificuldades operacionais das autoridades na detecção, investigação e punição célere e eficaz dos agentes infratores são algumas das razões para a crescente utilização de mecanismos pró-consensuais pelo Estado.

Seguindo as tendências e compromissos internacionais, o Sistema Brasileiro de Defesa da Concorrência (SBDC) incorporou técnicas especiais de investigação e mecanismos de consensualidade para resolver conflitos de interesses entre a Administração e os agentes infratores.

O acordo de leniência foi introduzido justamente como um dos mecanismos de otimização da efetividade estatal na repressão de ilícitos, na coleta de informações e documentos a partir dos próprios autores da infração, abreviando investigações de casos complexos e de difícil detecção, além de oportunizar ao infrator que tenha se arrependido do ilícito praticado, possa confessar seu envolvimento e com isso ter excluída ou diminuída sua punição em virtude da contribuição para as investigações e a cessação das condutas anticoncorrenciais. 
O Programa de Leniência Antitruste do Conselho Administrativo de Defesa Econômica (Cade) foi incluído na ordem jurídica no ano 2000, por intermédio de emenda à Lei no 8.884/1994 (BRASIL, 1994) e, atualmente, está previsto nos artigos 86 e 87 da Lei no 12.529/201133 (Lei de Defesa da Concorrência, ou LDC) (BRASIL, 2011) e Seção IV, artigos 197 a 211 do Regimento Interno do Cade (RICADE, BRASIL, 2020)4. Além das citadas normas, a negociação e a celebração do acordo de leniência antitruste também são orientadas pelo Guia do Programa de Leniência Antitruste do Cade, importante documento que consolida as melhores práticas e procedimentos adotados para negociação de acordos de leniência antitruste no Cade, e pelo recente Guia de Recomendações Probatórias para Propostas de Acordo de Leniência com o Cade, consolidado em setembro de 2021.

Considerado um dos principais instrumentos de repressão às infrações contra a Ordem Econômica no País e no mundo, em 2020 o Programa completou vinte anos. A formalização do primeiro acordo de leniência no Brasil ocorreu em 2003, no processo que investigou um cartel em licitações para serviço de vigilância privada realizada no Rio Grande do Sul. Desde então, mais de uma centena de acordos dessa natureza já foram assinados pela autoridade de defesa da concorrência brasileira.

Muito já se falou e ainda se fala sobre a declaração de cumprimento dos acordos de leniência pelo Tribunal do Cade. Alguns temas, todavia, ainda são pouco explorados e debatidos na doutrina, mas que, a despeito disto, não podem deixar de merecer a devida consideração. Questões relativas à realização de um controle de eficácia dos acordos de leniência pelo Tribunal Administrativo a partir da análise da efetividade da colaboração, baseada em critérios objetivos, do resultado útil do processo baseado em dados concretos, interessam sobremaneira ao Estado, na medida em que o Programa de Leniência objetiva que seja alcançado o melhor resultado para a resolução dos conflitos, além de evitar o desperdício de recursos públicos e privados.

Sob esse viés, analisa-se os três temas acima mencionados: (i) critérios objetivos para verificar a efetividade da colaboração; (ii) critérios objetivos para se alcançar o resultado útil do processo; e (iii) descumprimento do acordo de leniência por parte de seus signatários, diante da ausência de cooperação, e as consequências legais e materiais advindas dessa ocorrência. Destaca-se, além disto, que o Tribunal do Cade, por meio de suas decisões de declaração de cumprimento ou descumprimento dos acordos de leniência, realiza um verdadeiro controle de eficácia destes, tanto sob o aspecto formal do programa como, principalmente, sob o enfoque material de seus resultados, a evidenciar a importância dessas decisões.

\section{ASPECTOS FORMAIS DO ACORDO DE LENIÊNCIA ANTITRUSTE}

O Programa de Leniência Antitruste se constitui essencialmente de um conjunto de iniciativas direcionadas a detectar, investigar e punir infrações contra a Ordem Econômica, sendo um importan-

3 A Lei no 12.529/2011 trouxe modificações no Programa de Leniência Antitruste: alteração da autoridade competente para celebrar o acordo; o fim do impedimento para que o líder do cartel seja Proponente do acordo; e a ampliação dos ilícitos penais cobertos pela imunidade concedida ao signatário.

4 Aprovado pela Resolução no 22, de 19 de junho de 2019, e atualizado pela Emenda Regimental no 01/2020, de 2 de abril de 2020. 
te pilar da política de combate a condutas anticoncorrenciais, notadamente, os cartéis ${ }^{5}$, que constituem a mais grave espécie de ofensa à Ordem Econômica.

Considerando a sofisticação e complexidade que as relações podem assumir, em geral "não é fácil provar a existência de um cartel, de um acordo não escrito entre agentes econômicos, ainda mais se considerarmos que o comportamento paralelo pode decorrer das próprias características do mercado" (FORGIONI, 2016, p. 157).

Para além desse fato, que sinaliza a dificuldade da comprovação do conluio, os cartéis possuem relação direta com os grandes esquemas de corrupção, ex vi o famoso cartel formado pelas maiores empreiteiras do País, envolvidas em crimes financeiros, econômicos e tributários, corrupção, lavagem de dinheiro e infrações da Lei Anticorrupção, revelados no âmbito da "Operação Lavajato", ensejando a atraente manutenção de um sistema que se retroalimenta e não tem interesse no seu desmantelamento.

A frequente utilização do acordo de leniência no antitruste está calcada nas dificuldades operacionais da autoridade para exercer com efetividade suas funções punitivas, aos modernos e complexos ilícitos concertados, e aos efeitos não apenas repressivos, mas, também, preventivos da leniência (MARRARA, 2020, p. 90).

Outrossim, a cooperação instrutória dos signatários do acordo facilita a produção de provas de elevada complexidade e custo, sendo, portanto, um verdadeiro meio de promoção da celeridade na apuração de infrações contra a Ordem Econômica.

Se analisado sob uma perspectiva linear, o acordo de leniência é composto por diferentes fases e etapas. Na esfera antitruste, pode-se dizer que o acordo se fragmenta nas fases de (a) proposta, (b) negociação, (c) celebração, (d) execução e (e) extinção.

Cada uma dessas etapas envolve diferentes requisitos e análises de prospecção, sendo crucial que o programa tenha regras claras e transparentes, especialmente sobre a confidencialidade (GABAN; DOMINGUES, 2016, p. 329).

Sinteticamente, a fase de proposta envolve o pedido de marker, que é o ato de inciativa do proponente do acordo de leniência de entrar em contato com a Superintendência-Geral do Cade (SG/ Cade), a fim de comunicar o seu interesse em propor um acordo de leniência em relação a um determinado ilícito concorrencial e, assim, garantir que seja o primeiro proponente em relação ao ilícito. É uma espécie de "corrida" entre os participantes da infração para contatar a autoridade antitruste e reportar o ilícito.

A segunda fase, de negociação, envolve a apresentação de informações e documentos sobre a infração anticompetitiva noticiada, para que passe por análise técnica da Chefia de Gabinete da SG/Cade. Os tipos de documentos comumente recebidos pela Superintendência-Geral do Cade ${ }^{6}$ para

50 cartel pode ser conceituado como "o acordo, explícito ou implícito, entre concorrentes que atuem no mesmo mercado para obter vantagens competitivas, entre elas e principalmente, fixar preços ou quotas de produção, divisão de clientes e mercados de atuação, e neutralizar a concorrência." (FRANCESCHINI; BAGNOLI, 2018, p. 501).

6 Pergunta 48 do Guia do Programa de Leniência do Cade: “Normalmente, quais são os documentos que devem ser apresentados pelo proponente do Acordo de Leniência?" (Cade, Guia: Programa de Leniência Antitruste do Cade. 2016. Disponivel em https://www.gov.br/cade/pt-br/assuntos/programa-de-leniencia. Acesso em 17.3.2021). 
comprovação da conduta anticoncorrencial coletiva noticiada ou sob investigação, são os seguintes: (i) a troca de e-mails entre os concorrentes; (ii) a troca de e-mails entre pessoas da mesma empresa, relatando os ajustes entre concorrentes; (iii) troca de correspondências entre concorrentes; (iv) troca de correspondências entre pessoas da mesma empresa, relatando ajustes entre concorrentes; ( $v$ ) troca de mensagens de texto e/ou voz eletrônicas (SMS, WhatsApp, Skype etc.); (vi) agendas, anotações manuscritas, cadernos; (vii) gravações; (viii) tabelas e planilhas Excel; (ix) comprovantes de reuniões (atas, compromisso de Outlook, agendamento de salas, reservas de hotéis, extrato de cartão de crédito, comprovantes de viagens etc.); $(x)$ extratos telefônicos; (xi) cartões de visita de concorrentes; (xii) editais e atas de julgamento de certames etc.

Com base nas informações e documentos a serem entregues pelos proponentes é elaborado pela SG/Cade o "Histórico da Conduta", que contém a descrição detalhada da conduta anticompetitiva. Também podem ser realizadas entrevistas com as pessoas fisicas proponentes do acordo de leniência, a fim de obter mais informações e detalhes sobre os documentos apresentados e dos fatos reportados ao Cade. Não sendo apresentados documentos minimamente aptos a comprovar a infração relatada, poderá ser rejeitada a proposta de acordo de leniência pela SG/Cade, cuja avaliação será realizada caso a caso.

A terceira fase envolve a celebração do acordo, os trâmites para a formalização e sua assinatura. Nesta fase, a SG/Cade também inicia o contato com o(s) Ministério(s) Públicos(s) para apresentação do acordo de leniência. Importante ressaltar que em todas essas etapas há total confidencialidade, sendo tanto uma garantia quanto um dever do proponente, sob pena de prejudicar o bom andamento das investigações (artigo 86, § 9o-, da Lei no 12.529/2011) (BRASIL, 2011) e enfraquecer o Programa de Leniência Antitruste.

A Lei no 12.529/2011 não prevê expressamente a participação do Ministério Público na celebração dos acordos de leniência. No entanto, o fato de tal instrumento poder acarretar imunidade penal relativamente aos crimes praticados contra a Ordem Econômica (artigo 4으 da Lei no 8.137/1990), sendo o Ministério Público o titular privativo da ação penal pública, fez com que o Cade viabilizasse a participação do Parquet como agente interveniente no acordo. O Ministério Público que tem atuado nesta fase é aquele com atribuição para a matéria, podendo ser tanto o Ministério Público Estadual como o Ministério Público Federal' ${ }^{8}$. Saliente-se que o Representante do Ministério Público Federal

7 Pergunta 52 do Guia do Programa de Leniência do Cade: O Histórico da Conduta é um documento elaborado pela Superintendência-Geral do Cade que contém a descrição detalhada da conduta anticompetitiva, conforme entendimento da SG/Cade, com base nas informações e nos documentos apresentados pelo proponente do acordo de leniência (vide perguntas 46 e 47). Trata-se de documento elaborado e assinado pela SG/Cade, o qual não é assinado pelo proponente do acordo de leniência ou por seus advogados. (Cade, Guia: Programa de Leniência Antitruste do Cade. 2016. Disponível em https://www.gov. $\mathrm{br} / \mathrm{cade} / \mathrm{pt}$-br/assuntos/programa-de-leniencia. Acesso em 17.3.2021).

8 Como escreve Lafayete Josué Petter, o “membro do MPF pode, com total independência, promover a responsabilização a quem de direito, perante o Poder Judiciário, inclusive demandando contra as autoridades integrantes do Cade" (PETTER, 2009, p. 226) 
junto ao Cade ${ }^{9}$ ordinariamente não participa desse procedimento, tendo participação excepcional, situação que não impede seja aperfeiçoado o sistema, institucionalizando essa participação (LIMA, 2018, p. 19).

Após a celebração do acordo de leniência, inicia-se a fase da execução, na qual o proponente passa a ser denominado "signatário" do acordo de leniência. A partir desse momento o Cade poderá instaurar Inquérito Administrativo para apurar a infração noticiada no acordo de leniência, bem como realizar outras medidas de investigação do caso trazido ao seu conhecimento, como, por exemplo, a realização de busca e apreensão e/ou inspeção, requisição de informações e procedimentos de inteligência.

O artigo 207, § 1ำ, inciso VIII, do RICADE ${ }^{10}$, enumera as obrigações dos signatários do acordo de leniência, entre os quais o dever de mesmo após a assinatura do acordo de leniência, reportar à Superintendência-Geral do Cade novas informações e documentos referentes à infração noticiada, e portar-se com honestidade, lealdade e boa-fé.

Concluído o Inquérito Administrativo, comprovada suficientemente a infração noticiada no acordo de leniência, será instaurado o Processo Administrativo sancionatório pela SG/Cade, a fim de impor as sanções administrativas por infração à Ordem Econômica, ou no caso de não comprovação da infração, propor o seu arquivamento. Pode-se afirmar que apenas cessa o dever de cooperação do signatário com a autoridade após o julgamento de eventual Processo Administrativo pelo Tribunal do Cade.

A extinção do acordo de leniência apenas se dá no momento em que é mensurado e analisado pelo Tribunal do Cade se todos os termos do pacto foram cumpridos, ou não, pelas partes (artigo 86, §4으, da Lei no $12.529 / 2011)$ (BRASIL, 2011).

9 A atuação do Ministério Público Federal junto ao Cade possui previsão no art. 20 da Lei no 12.529/2011 (BRASIL, 2011). Ressalte-se que a OCDE na revisão pelos pares (peer review) do SBDC, ocorrida em 2010, destacou a singularidade da Representação do MPF junto ao Cade, afirmando que: “o papel do Ministério Público Federal é principalmente o de ser uma voz independente dentro da agência, representando o interesse público." (Organização para a Cooperação e Desenvolvimento Econômico - OCDE; Banco Interamericano de Desenvolvimento - BID. Lei e Política da Concorrência no Brasil - Uma Revisão pelos Pares. 2010. p. 43. Disponivel em: <http://www.oecd.org/daf/competition/45154401.pdf>. Acesso em: 8.3.2021. A revisão pelos pares anterior, de 2005, já havia reconhecido a relevância do MPF, aduzindo-se que este "tem como objetivo servir como 'cão de guarda' contra ilegalidades nas operações do Cade" (Organização para a Cooperação e Desenvolvimento Econômico - OCDE; Banco Interamericano de Desenvolvimento - BID. Lei e Política da Concorrência no Brasil - Uma Revisão pelos Pares. 2005. p. 48. Disponivel em: <http://www.oecd.org/brazil/35684126.pdf>. Acesso em: 8.3.2021).

10 Art. 207. Preenchidas as condições legais, o acordo de leniência será firmado com o Cade, por inter-médio da Superintendência-Geral, em, pelo menos, 1 (uma) via, reservando-se aos autos respectivos tratamento de acesso restrito. (...) VIII - obrigações do signatário do acordo de leniência: a) apresentar à Superintendência-Geral e a eventuais outras autoridades signatárias do acordo de leniência todas e quaisquer informações, documentos ou outros materiais de que detenham a posse, custódia ou controle, capazes de comprovar a infração noticiada ou sob investigação; b) apresentar à Superintendência-Geral e a eventuais outras autoridades signatárias do acordo de leniência todas e quaisquer novas informações, documentos ou outros materiais relevantes de que venham a ter conhecimento no curso das investiga-ções; c) apresentar todas e quaisquer informações, documentos ou outros materiais relacionados à práti-ca relatada de que detenham a posse, custódia ou controle, sempre que solicitado pela Superintendência-Geral e por eventuais outras autoridades signatárias do acordo de leniência no curso das investigações; d) cooperar plena e permanentemente com as investigações e o processo administrativo relacionado à infração relatada a ser conduzido pela Superintendência-Geral e eventuais outras autoridades signatárias do acordo de leniência; e) comparecer, quando solicitado, sob suas expensas, a todos os atos processuais até a decisão final sobre a infração noticiada, proferida pelo Cade; f) comunicar à Superintendência-Geral e a eventuais outras autoridades signatárias do acordo de leniência toda e qualquer alteração dos dados constantes no instrumento de acordo de leniência, inclusive os qualificadores; e g) portar-se com honestidade, lealdade e boa-fé durante o cumprimento dessas obrigações. 


\section{A EFETIVIDADE DA AÇÃO COLABORATIVA}

No âmbito do direito sancionador, deve-se fazer uma leitura harmônica da Constituição e da legislação vigente, sob a perspectiva dos princípios da eficiência, da razoabilidade e da proporcionalidade, que decorrem do devido processo legal, compreendido como processo justo e informador do processo administrativo.

Essa tônica deve perpassar todas as fases do acordo de leniência, desde a sua negociação, passando pela execução e culminando na extinção.

Ao ser analisado, ademais, é relevante sua compreensão como negócio jurídico consensual, cuja natureza contratual pressupõe o caráter sinalagmático na formação do instrumento da leniência, havendo a sujeição às obrigações recíprocas, tanto por parte do Poder Público quanto dos signatários.

Nessa perspectiva, a doutrina por vezes aproxima o acordo de leniência à colaboração premiada, explorando algumas de suas características comuns, dentre as quais o seu caráter sinalagmático (BONFIM; DIDIER JR., 2016, pp.114/115). Havendo a espontaneidade e a voluntariedade na adesão pelo infrator (autonomia da vontade), são assumidas obrigações recíprocas (aspecto sinalagmático), perfectibilizando o negócio jurídico.

No ano de 2017, a 5a Câmara de Coordenação e Revisão do Ministério Público Federal (5a CCR/ MPF), com atuação temática no combate à corrupção, dispôs em sua Nota Técnica no 01/201711, que o acordo de leniência é negócio jurídico consensual e que pressupõe obrigações recíprocas, constituídas sob a égide da proporcionalidade na consideração adequada do interesse público na celebração de seus termos:

...é espécie de ato jurídico convencional, com natureza dúplice: correlaciona uma técnica especial de investigação e um meio de defesa. Funda-se no reconhecimento e na confissão qualificada de práticas lesivas pela pessoa jurídica que delas se beneficiou, bem como na sua cooperação voluntária. Cuida-se de modo de confissão qualificado, porque não se esgota na admissão dos fatos nem com ela se confunde, estando profundamente ligado à cooperação ativa e plena no âmbito da atividade de procedimentos sancionadores, destacadamente moldado pelas obrigações assumidas na negociação $e$ atinentes à revelação ampla e efetiva de fatos ilícitos, com seus respectivos elementos de provas, bem como a indicação de pessoas fisicas e jurídicas envolvidas. (...) O acordo de leniência, como negócio jurídico consensual integrado à atividade sancionadora estatal pressupõe, além da espontaneidade e voluntariedade na adesão pelo infrator, obrigações recíprocas, constituídas sob a égide da proporcionalidade na consideração adequada do interesse público na celebração de seus termos. (5a CCR/MPF, BRASIL)

11 Nota Técnica no 1/2017 da 5ạ Câmara de Coordenação e Revisão do Ministério Público Federal (Disponível em: http:// www.mpf.mp.br/atuacao-tematica/ccr5/notas-tecnicas. Acesso em: 2.3.2021). 
Assim como na colaboração premiada ${ }^{12}$ o colaborador necessita efetivamente colaborar para receber o prêmio, sob pena de tratar-se de mera "premiação" acaso não haja a colaboração do autor do ilícito, do mesmo modo no acordo de leniência antitruste é necessário haver o efetivo cumprimento dos termos acordados para que o infrator receba os beneficios prometidos, sob pena de tratar-se de mera "leniência" se porventura não houver o cumprimento do pactuado pelo infrator, questões que colocam a indagação sobre os critérios objetivos que atendam à efetividade da colaboração, tal qual exigido pela norma.

De acordo com o artigo 86 da Lei no 12.529/2011 (BRASIL, 2011) existem obrigações essenciais a serem cumpridas pelos colaboradores, quais sejam, (i) a identificação dos demais envolvidos na infração; e (ii) a obtenção de informações e documentos que comprovem a infração noticiada ou sob investigação. 0 § 3ㅇ do artigo 86 do mencionado diploma legal ainda prevê que o acordo de leniência firmado com o Cade estipulará as condições necessárias para assegurar a efetividade da colaboração e o resultado útil do processo.

Entende-se, assim, que este conjunto de obrigações imposto legalmente, de identificação dos coautores e/ou partícipes da infração e a obtenção de informações e documentos que a comprovem, em respeito a melhor técnica jurídica do instrumento, está profundamente ligado à cooperação ativa e plena, moldada pelos encargos assumidos na negociação e atinentes a critérios objetivos de revelação ampla e efetiva de fatos ilícitos, com seus respectivos elementos de prova, bem como a indicação de pessoas físicas e jurídicas envolvidas, que pressupõe necessariamente utilidade e interesse públicos.

Diante do moderno conceito de acordo de leniência, como negócio jurídico consensual e meio de obtenção de prova, com finalidade e utilidade para as investigações e para o processo sancionador, há que se mensurar e analisar o conteúdo legal da efetividade da cooperação dos signatários e do resultado útil do processo:

“...para fins de julgamento do acordo e concessão final dos beneficios, será imprescindivel avaliar a efetividade dessa ação colaborativa. Além de ser guiada pela efetividade e continuidade da colaboração, o acordo de leniência vem relacionado, na legislação ordinária, com o 'resultado útil do processo' (art. 86, § 3o) (BRASIL, 2011)." (MARRARA, 2020, p. 93).

É que dentre as justificativas estatais para a adoção de um programa que concede beneficios em sede de acordo, estão previstas a obtenção de provas e a colaboração dos beneficiários, na perspectiva da plena eficiência e efetividade investigativa.

A eficiência e a efetividade possuem foco externo e estão relacionadas ao acesso antecipado às informações e documentos de difícil detecção e ao resultado proveitoso e bem-sucedido da colaboração. Por outro lado, "as provas tendem a consistir em informações e documentos 'internos' da prática ilícita, que muito possivelmente seriam dificeis de serem obtidos de outra forma que não por meio da colaboração" (ATHAYDE, 2019, p. 40).

12 No que diz respeito à colaboração premiada, menciona-se a Orientação Conjunta no $1 / 2018$, editada pelas 2 으 e 5 은 Câmaras de Coordenação e Revisão do Ministério Público Federal (Disponivel em: http://www.mpf.mp.br/atuacao-tematica/ ccr5/orientacoes. Acesso em: 2.3.2021). 
A razão da institucionalização do acordo de leniência, a toda evidência, é a busca de provas internas à estrutura delituosa, em tese rígida e compartimentada, valendo-se de pessoa com conhecimento privilegiado exatamente pela condição de ter atuado no acordo ilícito, ou em fatos delituosos por ela cometidos.

O acordo de leniência, destarte, também é utilizado como meio de obtenção de prova, e aqui reside uma de suas maiores justificativas, levando-se em conta a natureza, as circunstâncias, a gravidade e a repercussão social da conduta anticoncorrencial e a eficácia da colaboração.

Portanto, pode-se concluir que a obrigação dos signatários se relaciona, no mínimo, à apresentação de documentos e informações com lastro probatório acerca da existência das condutas anticompetitivas. 0 proponente, ainda na fase inicial, tem o dever de apresentar todas as informações das quais tenha conhecimento a respeito da infração noticiada, agir com boa-fé e não ocultar ou dissimular informações ou apresentar informações falsas/enganosas.

A questão que se coloca é quanto às obrigações do signatário, se elas se esgotam com a assinatura do acordo de leniência, com a entrega dos documentos que afirmou estarem em seu poder no momento da formalização, além da prestação de depoimentos e/ou informações sobre os fatos até o momento da formalização, ou se as obrigações persistem posteriormente, impondo o dever de continuar colaborando após a formalização do acordo para a materialização probatória dos fatos noticiados, e assim assegurar o resultado útil do processo. Partindo de uma interpretação sistemática, pode-se apontar que a obrigação deva continuar até que se alcance o resultado pretendido pela norma.

\section{O RESULTADO ÚTIL DO PROCESSO}

A Lei no 12.529/2011, em seu artigo 86, § 3으, prevê que o acordo de leniência firmado com o Cade estipulará as condições necessárias para assegurar a efetividade da colaboração e o "resultado útil do processo".

Em uma análise inicial, poder-se-ia imaginar que as obrigações do signatário se esgotam com a entrega dos documentos que afirmou estarem em seu poder, junto a prestação de depoimentos e/ou informações sobre os fatos até o momento da formalização do acordo de leniência, cabendo à autoridade administrativa responsável pela condução da negociação o ônus de decidir e responder pelo acordo celebrado. Se a negociação foi mal conduzida, ou se o signatário não tiver entregado os documentos suficientes para formalizar uma acusação em Processo Administrativo sancionatório, estaria liberado de todo e qualquer ônus posterior, pois caberia à autoridade negociadora o ônus de extrair os elementos para a certeza de uma acusação e, acaso não comprovada suficiente e exaustivamente a conduta ilícita, não celebrar o acordo de leniência.

Essa resposta resolveria de forma simples uma relação complexa e sofisticada de ilícitos de dificil comprovação, transferindo para a autoridade negociadora o encargo de esgotar todas as variantes e hipóteses possiveis, com carga praticamente absoluta de êxito, como que liberando o signatário de todo e qualquer ônus cooperativo posterior, como se fosse um negócio processual instantâneo.

Já outra resposta possivel, ao se interpretar o § 3o do artigo 86 conjuntamente com a redação de seu caput, seria tratar o acordo como uma obrigação de meio, qual seja, um negócio no qual o de- 
lator-colaborador assume o dever de manter um esforço dirigido para um resultado útil e proveitoso do processo tal qual previsto pela lei.

Partindo-se do pressuposto de que a lei não emprega palavras inúteis, mas tão somente necessárias, reputa-se a segunda interpretação mais adequada e em conformidade com os propósitos do Programa de Leniência Antitruste.

A busca objetiva do resultado útil do processo, a toda evidência, não significa a condenação dos agentes, nem tampouco a assunção de todo o ônus instrutório, mas sim o encargo de munir a autoridade administrativa antitruste de todos os elementos probatórios que possa ter acesso, seja no momento da assinatura do acordo, seja em momentos posteriores.

Observe-se que se a exigência para a realização dos acordos de leniência antitruste fosse o standart probatório pleno, seria desnecessário até mesmo instaurar o Inquérito Administrativo, como momento no qual são conduzidas diligências investigativas e instrutórias (v.g., requisições, oitivas, busca e apreensão etc.), ao que bastaria a instauração direta do Processo Administrativo sancionador, o que, sabe-se ser praticamente impossivel, diante da complexidade de um cartel.

$\mathrm{Na}$ realidade, os acordos de leniência partem de um conteúdo probatório inicial, que se presume seja útil a ponto de propiciar a realização e/ou a descoberta de outros elementos probatórios concretos, a partir dos quais possa ser extraída a realidade fática, para formar um conhecimento amplo de todo o ocorrido. Por isso mesmo, a colaboração aponta seja tratada como um meio e não um fim em si mesmo.

Partindo da ideia da utilidade da colaboração, sob a tônica da eficiência, é importante ressaltar que a partir dos elementos trazidos à autoridade antitruste em cooperação, seja possivel, por exemplo, realizar medidas cautelares como busca e apreensão (prevista no artigo 13, alínea "d", da Lei no 12.529/2011), inspeções, requisição de informações e procedimentos de inteligência. Deve-se propiciar, também, a obtenção de mais informações e documentos por meio de Termos de Compromisso de Cessação - TCCs com os eventuais partícipes do conluio que foram delatados.

No caso dos cartéis, por exemplo, as medidas cautelares são extremamente importantes devido à dificuldade na obtenção de provas, contando-se, nesses casos, com o elemento surpresa para que os investigados não inutilizem documentos, dados ou quaisquer outros elementos probatórios.

Ou seja, para fins de mensuração e análise do cumprimento do acordo de leniência antitruste pelo Tribunal do Cade, não se exige a assunção do standart probatório pleno, mas sim o comprometimento do delator-colaborador com a eficácia da ação colaborativa e com o resultado útil do processo.

Os critérios objetivos para alcançar tais obrigações previstas pela norma perfazem, necessariamente: (i) o fornecimento de informações, documentos e elementos que comprovem minimamente a infração relatada ou (ii) que indiquem à autoridade onde essas provas podem ser obtidas, fornecendo o fumus boni iuris para uma diligência investigativa eficaz (MARTINEZ, 2013, p. 265).

Em linhas gerais, o acordo de leniência, mesmo nas diferentes esferas de responsabilização, tanto na antitruste como na lei anticorrupção, por exemplo, tem como principal função propiciar a identificação dos demais envolvidos na infração e a comprovação do ilícito sob apuração:

O conjunto de leis sobreposto e fragmentado também dá algumas pistas 
sobre de que forma acordos de leniência mobilizarão funções diferentes. A Lei Anticorrupção é explícita ao dizer que a colaboração deve resultar em mais informações para alavancar investigações: a identificação dos demais envolvidos na infração e a comprovação do ilícito sob apuração. Sem dúvida, este é o objetivo enunciado do acordo de leniência, em linha com os tratados internacionais assinados pelo Brasil. (PIMENTA, 2020, p. 88).

Dessa forma, partindo-se dos critérios objetivos acima expostos e do resultado pretendido pela norma, com os dados concretos retromencionados, as decisões finais emanadas do Tribunal do Cade nos acordos de leniência, revestem-se de maior transparência, previsibilidade e segurança jurídica.

\section{BREVE PARALELO COM A ESFERA PENAL}

Quanto à eficácia da colaboração, em paralelo com a esfera penal, a nova "Lei Anticrime" (Lei no 13.964, de 2019, BRASIL), instituída para aperfeiçoar a legislação penal e processual penal, implementou maior disciplina à negociação com os colaboradores, promovendo alterações na Lei de Organização Criminosa. Estabeleceu-se o já consolidado entendimento doutrinário e jurisprudencial de que o acordo de colaboração premiada é "negócio jurídico processual" e "meio de obtenção de prova", o qual "pressupõe utilidade e interesse públicos", permanecendo a redação original de que "a sentença apreciará os termos do acordo homologado e sua eficácia" (artigo 3o-A e artigo 4으, § 11, ambos da Lei no 12.850/2013, BRASIL) $)^{13}$.

Em relação ao procedimento para a celebração do acordo de colaboração, é exigida a justificativa na hipótese de a proposta de acordo de colaboração premiada ser sumariamente indeferida, bem como a expressa vedação ao proponente, quando não celebrado o acordo por sua iniciativa, da utilização das informações fornecidas pelo colaborador de boa-fé (artigo 3ㅇ--B, §§ 1ㅇ e 6으, ambos da Lei no $12.850 / 2013)$.

Ao apreciar a Questão de Ordem na Petição no 7.074, julgada em 29.6.2017, o Supremo Tribunal Federal assentou o entendimento de que a aferição dos termos do acordo de colaboração, o seu cumprimento e a sua eficácia, se dá por ocasião da prolação da sentença final (no caso do STF, a competência é do Tribunal Pleno), como controle jurisdicional diferido, sendo atribuição do Relator homologar monocraticamente os acordos de colaboração premiada, na qual se restringe ao juízo de regularidade, sendo vedada a participação do juiz nas negociações (artigo 4으, §§ 60 e 11, da Lei no 12.850/2013), conferindo, assim, concretude ao princípio acusatório, que rege o processo penal no Estado Democrático de Direito:

QUESTÃO DE ORDEM EM PETIÇÃO. COLABORAÇÃO PREMIADA. I. DECISÃO INICIAL DE HOMOLOGAÇÃO JUDICIAL: LIMITES E ATRIBUIÇÃO. REGULARIDADE, LEGALIDADE E VOLUNTARIEDADE DO ACORDO. MEIO DE OBTENÇÃO DE PRO-

13 Art. 3ㅇ-A. O acordo de colaboração premiada é negócio jurídico processual e meio de obtenção de prova, que pressupõe utilidade e interesse públicos. (Incluído pela Lei no 13.964, de 2019).

Art. 40 0 juiz poderá, a requerimento das partes, conceder o perdão judicial, reduzir em até $2 / 3$ (dois terços) a pena privativa de liberdade ou substituí-la por restritiva de direitos daquele que tenha colabora-do efetiva e voluntariamente com a investigação e com o processo criminal, desde que dessa colabora-ção advenha um ou mais dos seguintes resultados: (...) § 11. A sentença apreciará os termos do acordo homologado e sua eficácia. 
VA. PODERES INSTRUTÓRIOS DO RELATOR. RISTF. PRECEDENTES. II. DECISÃO FINAL DE MÉRITO. AFERIÇÃO DOS TERMOS E DA EFICÁCIA DA COLABORAÇÃO. CONTROLE JURISDICIONAL DIFERIDO. COMPETÊNCIA COLEGIADA NO SUPREMO TRIBUNAL FEDERAL.

1. Nos moldes do decidido no HC 127.483, Rel. Min. DIAS TOFFOLI, Tribunal Pleno, DJe de 3.2.2016, reafirma-se a atribuição ao Relator, como corolário dos poderes instrutórios que lhe são conferidos pelo Regimento Interno do STF, para ordenar a realização de meios de obtenção de prova (art. 21, I e II do RISTF), a fim de, monocraticamente, homologar acordos de colaboração premiada, oportunidade na qual se restringe ao juízo de regularidade, legalidade e voluntariedade da avença, nos limites do art. 4므, § 7o-, da Lei n. $12.850 / 2013$.

2. O juízo sobre os termos do acordo de colaboração, seu cumprimento e sua eficácia, conforme preceitua o art. 40., § 11, da Lei n. 12.850/2013, dá-se por ocasião da prolação da sentença (e no Supremo Tribunal Federal, em decisão colegiada), não se impondo na fase homologatória tal exame previsto pela lei como controle jurisdicional diferido, sob pena de malferir a norma prevista no $\S 60$ do art. 40 da referida Lei $n .12 .850 / 2013$, que veda a participação do juiz nas negociações, conferindo, assim, concretude ao princípio acusatório que rege o processo penal no Estado Democrático de Direito.

3. Questão de ordem que se desdobra em três pontos para: (i) resguardar a competência do Tribunal Pleno para o julgamento de mérito sobre os termos e a eficácia da colaboração, (ii) reafirmar, dentre os poderes instrutórios do Relator (art. 21 do RISTF), a atribuição para homologar acordo de colaboração premiada; (iii) salvo ilegalidade superveniente apta a justificar nulidade ou anulação do negócio jurídico, acordo homologado como regular, voluntário e legal, em regra, deve ser observado mediante o cumprimento dos deveres assumidos pelo colaborador, sendo, nos termos do art. 966, § 4으, do Código de Processo Civil, possivel ao Plenário analisar sua legalidade. (SUPREMO TRIBUNAL FEDERAL, Pet no 7.074-QO, Tribunal Pleno, Relator Min. Edson Fachin, v.m., Dje-STF de 3.5.2018).

O Relator, Ministro Edson Fachin, teceu considerações sobre a necessidade de análise da eficácia da colaboração premiada e da competência do colegiado do Tribunal para avaliar o cumprimento dos termos do acordo de colaboração premiada:

...Como se verifica da dicção legal, é no julgamento de mérito que o Poder Judiciário, então, como autorizado pela lei, poderá definir a extensão da colaboração e por consequência analisar o benefício respectivo.

A legislação permite ao Judiciário, em tal fase diferida, após a conclusão da instrução probatória, avaliar se os termos da colaboração premiada foram cumpridos, bem como se os resultados concretos foram atingidos, o que 
definirá, logicamente, a sua eficácia, para utilizar o vocábulo da lei. Por isso mesmo, a colaboração é um meio e não um fim em si mesmo. (STF, Pet no 7.074-QO, BRASIL).

O voto do Ministro Luis Roberto Barroso ${ }^{14}$ consignou que o Estado deve ser leal ao colaborador, e que apenas no caso de o colaborador não entregar aquilo a que se comprometeu é que se poderá invocar a cláusula do contrato não cumprido.

Para fins de eficácia e concessão dos benefícios ao colaborador, é imprescindivel avaliar se os termos da colaboração foram cumpridos, bem como se os resultados concretos foram atingidos.

Dessarte, na esfera penal, o Judiciário exercerá o controle de eficácia dos acordos de colaboração, ao prolatar a sentença final, por meio da análise do cumprimento do pactuado e dos resultados úteis alcançados com a colaboração.

\section{O TRIBUNAL ADMINISTRATIVO DO CADE E O CONTROLE DE EFICÁCIA DO ACORDO DE LENIÊNCIA ANTITRUSTE}

A concessão dos beneficios premiais previstos no Acordo de Leniência está necessariamente condicionada ao efetivo adimplemento das obrigações que tenham sido assumidas pelo signatário e de que advenham os resultados indicados pela norma. Essa assertiva conduz à análise da extensão da colaboração, bem como se os resultados concretos foram atingidos, o que definirá, logicamente, a eficácia da colaboração e o respectivo benefício.

A respeito da avaliação e mensuração da eficácia da colaboração e a consequente aplicação dos beneficios legais, a legislação antitruste (artigo 86, § 4으, incisos I e II, da Lei oㅡ 12.529/2011'15) e o

14 Consta do voto do Ministro Luis Roberto Barroso: “E, aqui, o que a lei específica estabelece, a Lei 12.850, no art. 4으, § 11, é que caberá ao Judiciário, no momento do julgamento: ‘§ 11. A sentença apreciará os termos do acordo homologado e sua eficácia.' A minha interpretação desta cláusula é que, no momento do julgamento, o que se vai fazer é verificar se o que foi clausulado no acordo, se aquilo a que o colaborador premiado se obrigou, ele efetivamente cumpriu e de maneira satisfatória. Esta é a atuação do Poder Judiciário ao valorar a colaboração premiada depois que ela tenha sido homologada lá atrás, no momento da sua celebração. Logo, no momento do julgamento, já não cabe mais juízo de legalidade ou juízo de mérito sobre a colaboração. Esse juízo terá sido feito no momento da homologação. Estou convencido de que a colaboração premiada, uma vez homologada, só não será honrada se o colaborador não cumprir com as obrigações que assumiu. Porque, do contrário, se o Estado, pelo seu órgão de acusação, firma um acordo de colaboração premiada que ele, Estado, valorou ser do seu interesse, obtém as informações para punir réus mais perigosos ou crimes mais graves - e, portanto, se beneficia do colaborador -, e depois não cumpre o que ajustou, é uma deslealdade por parte do Estado e é a desmoralização total do instituto da colaboração premiada. O Estado tem que ser leal. O Estado tem que cumprir a sua palavra, tanto quanto o colaborador. E o Estado só pode invocar as 'cláusulas do contrato não cumprido' se o colaborador não entregar aquilo a que se comprometeu." (STF, Pet no 7074-QO).

15 Art. 86. (...) § 4 o Compete ao Tribunal, por ocasião do julgamento do processo administrativo, verificado o cumprimento do acordo: I - decretar a extinção da ação punitiva da administração pública em favor do infrator, nas hipóteses em que a proposta de acordo tiver sido apresentada à Superintendência-Geral sem que essa tivesse conhecimento prévio da infração noticiada; ou II - nas demais hipóteses, reduzir de 1 (um) a 2/3 (dois terços) as penas aplicáveis, observado o disposto no art. 45 desta Lei, devendo ainda considerar na gradação da pena a efetividade da colaboração prestada e a boa-fé do infrator no cumprimento do acordo de leniência. 
Regimento Interno do Cade (artigo 209, incisos I e II, do RICADE ${ }^{16}$ ) preveem que compete ao Tribunal Administrativo do Cade verificar o cumprimento do acordo de leniência. Ao que se conclui que a análise do cumprimento do acordo de leniência é ato administrativo de competência exclusiva do Tribunal Administrativo.

O Guia do Programa de Leniência do Cade também estabelece que a decisão final, proferida pelo Tribunal do Cade por ocasião do julgamento do processo administrativo, avaliará se as condições e cláusulas estipuladas no acordo foram ou não cumpridas, e se a empresa e/ou pessoa física signatária responsável pelo descumprimento perderá os beneficios em relação às multas e demais sanções cabiveis.

Instaura-se, assim, um novo capítulo para a análise da eficácia e do resultado útil da colaboração, pois para declarar o acordo de leniência cumprido, o Tribunal Administrativo deverá verificar, ao final da colaboração, a presença dos resultados previstos nos incisos I e II e no caput do artigo 86 da Lei no 12.529/2011, quando o conjunto probatório reunido nos autos deverá ser suficiente para a identificação dos demais envolvidos na infração noticiada e para a comprovação da infração apontada.

Assim, diferentemente do momento da celebração do acordo de leniência no âmbito da Superintendência-Geral, o legislador definiu o padrão probatório mínimo que autoriza o Tribunal Administrativo a conceder os benefícios legais aos signatários da leniência, ao final da colaboração.

Utilizando-se das lições de Pontes de Miranda (MIRANDA, 2000, p. 62 ss.) sobre os negócios jurídicos e a conhecida "escada ponteana", os negócios jurídicos passam pelos planos de existência, validade e eficácia. No plano da existência (ótica do "ser") identifica-se na leniência o fato como ele é, ou seja, a existência de conduta anticompetitiva que possa vir a ser delatada por uma pessoa física ou jurídica à autoridade antitruste. Já no plano de validade (ótica da "norma jurídica") se identificam os requisitos legais para que a leniência ocorra, tais como a voluntariedade, a espontaneidade, quais informações devam ser prestadas e todo o mais concernente à legalidade do ato. Por fim, o plano de eficácia (ótica da "produção dos efeitos do ato") se dá quando o acordo de leniência operará seus efeitos regulares, caso naturalmente seja homologado, momento no qual os benefícios serão concedidos aos signatários.

Identificando-se vícios no plano de validade, o acordo de leniência pode ser anulado, como ocorreria na hipótese de vício de vontade ou de consentimento, acarretando a invalidade do negócio jurídico como um todo, retirando-o por completo do mundo jurídico, inclusive privando-o de seus efeitos. Nessa hipótese, nenhuma das provas coletadas durante a negociação do acordo poderia ser utilizada. Os procedimentos de confidencialidade do Cade, na fase de formalização do acordo de leniência, estão especificados no Guia do Programa de Leniência Antitruste ${ }^{17}$.

16 Art. 208. Uma vez declarado o cumprimento do acordo de leniência pelo Cade, será decretada em favor do signatário do acordo de leniência: I - a extinção da ação punitiva da administração pública, nas hipóteses em que a proposta do acordo de leniência tiver sido apresentada à Superintendência-Geral sem que essa tivesse conhecimento prévio da infração noticiada; ou II - nas demais hipóteses, a redução de um a dois terços das penas aplicáveis na seara administrativa.

17 Pergunta 75 do Guia do Programa de Leniência do Cade: “Quais são os procedimentos de confidencialidade do Cade na fase de formalização do Acordo de Leniência?" (Cade, Guia: Programa de Leniência Antitruste do Cade. 2016. Disponível em: https://www.gov.br/cade/pt-br/assuntos/programa-de-leniencia/guia-do-programa-de-leniencia. Acesso em: 18.3.2021). 
Sendo existente e válido, o acordo de leniência chegará até a fase de controle de sua eficácia, quando será analisada a extensão da colaboração, o cumprimento ou não das obrigações assumidas, e por consequência os beneficios respectivos. Avaliar-se-á se os termos do acordo de leniência foram cumpridos, bem como se os resultados concretos foram atingidos.

A consequência natural a partir do atendimento integral das obrigações assumidas no acordo é a declaração de seu cumprimento pelo Tribunal Administrativo, com a extinção da punibilidade do infrator, além da imunidade penal para as pessoas físicas.

Não fosse assim, se as obrigações do signatário se esgotassem na assinatura do acordo de leniência, com a entrega única dos documentos que estivessem em seu poder, com a prestação de depoimento ou entrega de informações até aquele momento, a atribuição da verificação do cumprimento do acordo seria da Superintendência-Geral do Cade, autoridade competente para a sua celebração, com estrita observância dos requisitos formais (artigo 86, caput, da Lei no 12.529/2011).

No entanto, como se afirma, as obrigações do signatário persistem posteriormente à assinatura do acordo de leniência, cujo dever de continuar colaborando se protrai no tempo até a materialização probatória dos fatos noticiados ou, ao menos, até esgotadas todas as possibilidades investigatórias para tanto, sendo que a atribuição da verificação do cumprimento material do pactuado é do Tribunal Administrativo, por ocasião do julgamento do Processo Administrativo Sancionador (artigo 86, § 4으, da Lei no 12.529/2011).

Assim, pode-se afirmar que o acordo de leniência é existente e válido desde o momento de sua celebração pela Superintendência-Geral do Cade e, quando da remessa dos autos do Processo Administrativo ao Tribunal do Cade para julgamento, a decisão do Plenário sobre o cumprimento ou o descumprimento do acordo desencadeará outros efeitos jurídicos previstos na Lei no 12.529/2011, a depender da decisão do colegiado.

Os efeitos previstos em lei são os seguintes: extinção da ação punitiva da Administração Pública ou a redução das penas aplicáveis (artigo 86, §4으, incisos I e II); e extinção da punibilidade dos crimes referidos no caput do artigo 87 (artigo 87, parágrafo único), ou o impedimento dos signatários para a celebração de novo acordo de leniência com o Cade por três anos (artigo 86, § 12), a depender da direção do vetor da decisão do Tribunal Administrativo, que poderá ser pelo cumprimento ou descumprimento do acordo.

O Tribunal Administrativo, desse modo, exercerá um verdadeiro e relevante controle de eficácia (formal e material) dos acordos de leniência e do resultado útil das colaborações pactuadas na Superintendência-Geral do Cade.

\section{DESCUMPRIMENTO DO ACORDO DE LENIÊNCIA ANTITRUSTE E AS CONSEQUÊNCIAS ADVINDAS}

O Guia do Programa de Leniência do Cade, ao tratar do descumprimento do acordo ${ }^{18}$, não exaure as causas que o ensejam, apenas menciona, a título exemplificativo, que podem ensejar a de-

18 Pergunta 77 do Guia do Programa de Leniência do Cade: “O que ocorre se não forem cumpridas as condições e cláusulas estipuladas no Acordo de Leniência?" (Cade, Guia: Programa de Leniência Antitruste do Cade. 2016. Disponível em: https:// www.gov.br/cade/pt-br/assuntos/programa-de-leniencia/guia-do-programa-de-leniencia. Acesso em: 17.3.2021). 
cisão de descumprimento a ausência de cooperação com o Cade ou a apresentação de informações falsas, esclarecendo que não se considera, via de regra - como já anteriormente afirmado - "descumprimento do Acordo de Leniência o fato de o Tribunal do Cade não condenar todas as empresas e/ou pessoas físicas identificadas como participantes da infração noticiada pelos signatários."

Esse tópico levanta a questão da ausência de colaboração com o Cade, compreendendo-se esta a partir do descumprimento das obrigações assumidas quando da realização do acordo de leniência e da inutilidade da cooperação.

Ora, se a colaboração deve ser tomada como um meio e não um fim em si mesmo, de modo que para a declaração de cumprimento do acordo de leniência antitruste não se está a falar de standart probatório pleno, necessário para embasar uma condenação, mas sim do integral e pleno atendimento das obrigações assumidas quando da realização e assunção do pacto e da utilidade da cooperação, devendo ser compreendida no sentido objetivo de propiciar a realização e/ou a descoberta de outros elementos probatórios concretos, seja a partir da realização de diligências, medidas cautelares ou da assinatura de termos de compromisso de cessação com coautores/partícipes, a partir dos quais possa ser extraída a realidade fática para formar um conhecimento do ocorrido, é correto afirmar que, quando referidos objetivos impostos pela norma não são alcançados, o acordo de leniência deve ser considerado descumprido por seus signatários, tal qual previsto no Guia do Programa de Leniência do Cade.

Um exemplo elucidativo desta hipótese pode ocorrer nos casos de arquivamento de Inquérito Administrativo por insuficiência probatória, que não produz coisa julgada material, atrelado a um prévio acordo de leniência na esfera antitruste.

É indicativa a exclusão da possibilidade de um acordo de leniência ser declarado cumprido nas hipóteses em que as investigações não evoluam para a produção de outras provas para a imposição de sanções por infração à Ordem Econômica, salvo se suficientemente comprovada a infração no momento em que firmado o acordo ou se os fatos apurados na instrução não configurem infração.

Não é concebível que o inquérito administrativo ou o processo administrativo instaurado a partir do momento em que a autoridade detenha "informações e documentos que comprovem a infração noticiada ou sob investigação" e a identidade dos envolvidos na infração (incisos I e II do caput do artigo 86 da Lei no 12.529/2011), não sejam suficientes para apurar os fatos relativos ao Histórico da Conduta elaborado pela Superintendência-Geral do Cade, no qual está contida a descrição detalhada da conduta anticompetitiva, o que, repita-se, não é necessário configure infração, mas que possibilite o pleno conhecimento fático.

Diante disso, quando reconhecida a ausência de cooperação do signatário, que (i) não tenha fornecido informações, documentos e elementos que comprovem minimamente a infração relatada, ou (ii) que não tenha indicado à autoridade onde essas provas poderiam ser obtidas, é de se reconhecer o descumprimento do acordo, considerando o comando legal previsto no artigo 86, caput, e § 3으, da Lei no $12.529 / 2011$.

Uma das consequências da declaração de descumprimento do acordo por ausência de cooperação atrelado ao arquivamento de inquérito administrativo por insuficiência probatória, é a ausência de coisa julgada material e a possibilidade de reabertura das investigações acaso advenham 
novas provas e documentos da infração à Ordem Econômica.

A respeito do arquivamento de inquérito policial por insuficiência probatória, o Superior Tribunal de Justiça já assentou o entendimento de que a decisão de arquivamento do inquérito por "insuficiência probatória" não gera coisa julgada material, sendo possivel a reabertura das investigações na hipótese de "surgirem novos elementos de convicção"19.

Fazendo-se um paralelo com as investigações no âmbito do antitruste, eventuais decisões da Superintendência-Geral do Cade de arquivamento de inquérito administrativo por insubsistência probatória não produzirão coisa julgada material.

Ademais, os acordos de leniência firmados com a autoridade antitruste podem prever que os signatários estão cientes de que, no caso de desistência tardia ou descumprimento do acordo, as informações e documentos apresentados relativos à infração relatada poderão ser utilizados em procedimentos que poderão ser instaurados ou propostos pela SG/Cade ou Ministério Público Federal.

É dedutivel que a razão dessa cláusula advém do entendimento de que o acordo, embora existente e válido, mostrou-se ineficaz diante da desistência tardia (após firmado o acordo) ou do descumprimento do pactuado a ponto de não poder render beneficios premiais ao signatário. A perda dos seus efeitos, no entanto, não impede a utilização das informações e documentos no futuro, justamente pelo fato de ser considerado existente e válido.

Situação diversa é aquela prevista no artigo 86, § 9으, da Lei no 12.529/2011 (BRASIL, 2011), e no artigo 206, § 3으, do RICADE (BRASIL, 2020), no sentido de que as informações e documentos apresentados pelo proponente durante a fase de negociação do acordo de leniência, subsequentemente frustrado ou rejeitado, não poderão ser utilizadas para quaisquer fins pelas autoridades que a eles tiveram acesso.

Há, portanto, diferenças consideráveis relativas à possibilidade ou não de utilização das informações e documentos apresentados, a depender da fase de extinção do acordo.

Se a negociação do acordo, na fase inicial, for infrutífera, as informações e documentos apresentados não poderão ser utilizados para quaisquer fins, mas se houver desistência após firmado ou se o acordo for descumprido pelo signatário, situações a serem apuradas ao final, é possível a previsão no acordo pactuado acerca da possibilidade de utilização das informações e dos documentos apresentados relativos à infração relatada em procedimentos que poderão ser instaurados ou propostos pela Superintendência-Geral do Cade ou pelo Ministério Público Federal.

Outra consequência legal e importante a partir da declaração do descumprimento do acordo de leniência antitruste é a pena de impedimento para celebração de novo acordo de leniência pelo prazo de três anos, contado da data de seu julgamento, situação prevista no artigo 86, § 12, da Lei no $12.529 / 2011$.

Tal consequência, segunda a Doutrina Jurídica, funciona como uma espécie de ônus pela não

19 "Nos termos do artigo 18 do Código de Processo Penal e do verbete 524 da Súmula do Supremo Tribunal Federal, a decisão de arquivamento do inquérito por insuficiência probatória não gera coisa julgada material, sendo possivel a reabertura das investigações se surgirem novos elementos de convicção." (STJ, RHC no 63.510/RS, Rel. Min. Jorge Mussi, 5a Turma, j. 20.9.2016, Dje-STJ de 28.9.2016). 
cooperação efetiva:

...trata-se de importante mecanismo à mão do Cade para aumentar os custos de não cooperação. (...) o legislador parece ter-se centrado em dificultar nova chance de leniência no mesmo caso (se houver arquivamento por falta de provas, v.g., e o agente desejar evitar sofrer novo processo pela mesma conduta, se trazidos fatos novos). (TAUFICK, 2017)20

As situações ora postas e analisadas demonstram as consequências legais e materiais advindas da declaração de descumprimento dos acordos de leniência pelo Tribunal Administrativo, diante da ausência de cooperação e a importância e a relevância das obrigações assumidas por ocasião da assinatura do pacto por parte dos signatários, especialmente nos casos de não entrega ou entrega incompleta de documentos e informações prometidas, e diante da constatação da ausência de efetiva e eficaz cooperação, situações que podem culminar no arquivamento do inquérito administrativo por insuficiência de elementos probatórios mínimos.

Saliente-se que a decisão declarando o descumprimento do acordo de leniência pelo Tribunal do Cade quando comprovado o não atendimento de obrigações assumidas pelos signatários, poderá render efeitos pedagógicos e reflexos no Sistema Antitruste, na medida em que contribuirá para a solidificação do real significado do agente colaborador e da eficácia e utilidade dos acordos de leniência, evitando-se a frustração da expectativa gerada, além de conferir maior segurança jurídica e previsibilidade.

Acresça-se que os signatários também são favorecidos ao assumirem a posição prioritária para assinarem o acordo antes dos demais investigados e partícipes do ilícito, e com isso obterem os melhores beneficios (artigo 86, § 1으, inciso I c/c os §§ 7으 e 8으, da Lei ㄲo 12.529/2011).

Deve-se, portanto, mensurar e calibrar todos os efeitos que poderão advir das decisões emanadas pelo Tribunal Administrativo, tanto no sentido da declaração do cumprimento ou descumprimento dos acordos de leniência, cuja seriedade de seu tratamento solidificará o Programa de Leniência Antitruste do Cade, mesmo que seja reconhecendo o seu descumprimento, pois representará um tratamento justo para com os que cumprem o acordado, não servindo de estímulo a não observância do pactuado.

O acordo de leniência é um instrumento bilateral, que deve ser cumprido pelos signatários para que obtenham os beneficios ajustados perante a autoridade antitruste. No caso de seu descumprimento, não poderá render benefícios aos signatários, sob pena de tornar o acordo de leniência um instrumento não bilateral gerador de benefícios apenas para uma das partes.

\section{CASUÍSTICA}

No final de 2017, o Tribunal Administrativo do CADE apreciou dois casos relacionados ao mercado de autopeças, que culminaram no arquivamento das investigações iniciadas por acordo de leniência. Entendeu a Corte Colegiada que os signatários cumpriram o requisito de que a cooperação resultasse na identificação dos demais participantes da infração e na obtenção de informações e 
documentos que comprovassem a infração noticiada ou sob investigação, e que a não condenação não significou, naqueles autos, o descumprimento dos requisitos do acordado.

Nos autos do Processo Administrativo no 08700.008004/2017-1521, de relatoria do Conselheiro Paulo Burnier da Silveira, o Acordo de Leniência foi homologado, em conformidade com a conclusão da SG/Cade e o parecer do Ministério Público Federal junto ao Cade (MPF/Cade), sob o fundamento de que a decisão de arquivamento do inquérito não resultou da insuficiência das provas trazidas pelos signatários do acordo, mas de particularidades do mercado em análise.

No mesmo sentido foi a decisão proferida no Processo Administrativo no 08700.008005/2017$51^{22}$, agora da relatoria do Conselheiro João Paulo de Resende, cuja decisão de arquivamento do Inquérito Administrativo não foi baseada na insuficiência de documentos e informações trazidas pelos signatários do Acordo de Leniência, mas em particularidades do mercado em análise.

Em outra oportunidade, em 2019, o Tribunal do Cade arquivou por insuficiência de provas o Processo Administrativo no 08700.010320/2012-34²3 suposto cartel no mercado nacional independente de reposição de peças de para-brisas), de relatoria da Conselheira Polyanna Ferreira Silva Vilanova, e homologou o Acordo de Leniência, divergindo dos pareceres da Procuradoria Federal Especializada (ProCADE) e do Ministério Público Federal (MPF/Cade), que se manifestaram no sentido do descumprimento das obrigações pelos signatários do acordo.

Nos termos do voto da Relatora, que foi acompanhado pelos demais Conselheiros do Tribu-

21 “Conforme se verifica nos autos (SEI no 003263) e na Nota Técnica no 28/2017 da SG (SEI no 0312027), os Signatários cumpriram as obrigações estipuladas no Acordo de Leniência, uma vez que (i) identifica-ram os participantes da suposta infração notificada (fls. 28-29) e (ii) apresentaram Histórico de Conduta detalhado (fls. 22-38) com documentos que indicavam a ocorrência de infração à ordem econômica (fls. 123-180). (...) A decisão de arquivamento do inquérito, portanto, não resultou da insuficiência das pro-vas trazidas pelos Signatários do Acordo de Leniência, mas sim de particularidades do mercado de pro-dutos de iluminação automotiva [ACESSO RESTRITO] que sugerem a prática de dual sourcing." (BRASIL, TRIBUNAL DO CADE, Processo Administrativo no 08700.008004/2017-15, Voto condutor proferido pelo Relator, Conselheiro Paulo Burnier da Silveira, 13.12.2017) (SEI/Cade no 0423982).

22 "Conforme se verifica nos autos e na Nota Técnica no 25/2017 da SG (SEI 0311877), os Signatários cumpriram as obrigações estipuladas no Acordo de Leniência, uma vez que (i) identificaram os partici-pantes da suposta infração notificada e (ii) apresentaram Histórico de Conduta detalhado com docu-mentos que indicavam a suposta ocorrência de infração à ordem econômica. (...) A decisão de arquiva-mento do inquérito, portanto, não resultou da inexistência de colaboração pelos Signatários do Acordo de Leniência, mas sim de particularidades do mercado de [ACESSO RESTRITO] que sugerem a prática de dual sourcing." (BRASIL, TRIBUNAL DO CADE, Processo Administrativo no 08700.008005/2017-51, Voto condutor proferido pelo Relator, Conselheiro João Paulo de Resende, 13.12.2017) (SEI/CADE no 0425540).

23 "Quanto aos posicionamentos divergentes da PFE e MPF pela não concessão dos benefícios aos signatá-rios, culpando-os de terem causado 'falhas' ou 'entraves à instrução', registro discordância pelos seguin-tes motivos: (i) está mais que comprovado nos autos que os signatários foram diligentes na apresentação das provas desde a assinatura do acordo de leniência e em todos os momentos que foram chamados aos autos a complementar tais diligências; (ii) eventuais negativas ou incongruências nos depoimento dos representados não infirmam a colaboração da leniente (é preciso aqui ter cuidado ao sopesar as estraté-gias e argumentos de defesa com os atos instrutórios do feito); (iii) eventual incongruência entre os depo-imentos de signatários devem ser confrontados com elementos probantes robustos, o que a PFE, salvo melhor juízo, não logrou êxito; (iv) quanto à afirmação de que o resultado útil perseguido pela norma não foi alcançado, qual seja, a de reunir provas da investigação noticiada, tanto a PFE quanto o MPF, ao meu ver, ignoraram os esforços e pronto atendimento feitos pela leniente ao longo do processo para incumbir a ela todo o ônus de produção de prova, ignorando a inversão que acarreta também esta au-tarquia; (v) por fim, os signatários possuem histórico de outras duas leniências em mercados de autopar-tes homologadas por este Conselho - o que reitera a postura de colaboração dos mesmos, bem como assegura que não há óbices para conceder os benefícios." (BRASIL, TRIBUNAL DO CADE, Processo Administrativo no 08700.010320/2012-34, Voto condutor proferido pela Relatora, Conselheira Polyanna Ferreira Silva Vilanova, 1‥7.2019) (SEI/CADE no 0632252). 
nal do Cade, entendeu-se que, apesar de os elementos probatórios terem sido considerados insuficientes e de o Inquérito Administrativo ter sido arquivado por este motivo, o Acordo de Leniência foi considerado cumprido. O Tribunal do Cade, seguindo o entendimento da SG/Cade, homologou o acordo concedendo aos signatários os benefícios legais.

Saliente-se que, em 2021, iniciado na sua 174 a 24 e concluído na $175 \underline{a}^{25}$ Sessão Ordinária de Julgamento, o Plenário do Tribunal Administrativo do Cade julgou, por maioria de votos, o Inquérito Administrativo no 08700.003246/2017-12, decretando a extinção da ação punitiva da Administração Pública em favor dos infratores signatários, nos termos do artigo 86, § 4으, inciso I, da Lei no 12.529/2011. Tratou-se de caso de arquivamento de Inquérito Administrativo por insuficiência probatória, decisão que competiu à Superintendência-Geral do Cade, e posterior declaração de cumprimento de acordo de leniência com a extinção da punibilidade dos signatários, pelo Tribunal Administrativo do Cade.

No Parecer do Ministério Público Federal junto ao Cade ${ }^{26}$, apresentado pelo Procurador Regional da República Waldir Alves, foi sustentado o não cumprimento do Acordo de Leniência, destacando que a decisão de arquivamento do Inquérito Administrativo pela Superintendência-Geral do Cade se baseou no artigo 13, inciso IV, da Lei no 12.529/2011, c/c o artigo 141 do RICADE, ou seja, na “insubsistência dos indícios", revelando, uma vez mais, a ausência de material probatório, e que a insuficiência de provas não gera coisa julgada material, sendo possivel a reabertura das investigações acaso surjam novas provas e elementos de convicção.

No debate estabelecido na deliberação sobre o caso, na Primeira Sessão de Julgamento (174a Sessão Ordinária, de 31.3.202127), o Relator Conselheiro Sérgio Costa Ravagnani entendeu que foi descumprido o Acordo de Leniência, diante da “inexistência dos resultados previstos nos incisos I e II do caput do art. 86 da Lei no 12.529/2011", além de descumprida Cláusula específica do acordo.

Na continuidade do debate, na Segunda Sessão de Julgamento (175a Sessão Ordinária, de

24 https://www.gov.br/cade/pt-br/assuntos/sessoes/2021/174a-sessao-ordinaria. Acesso em 23.9.2021.

25 https://www.gov.br/cade/pt-br/assuntos/sessoes/2021/175a-sessao-ordinaria. Acesso em 23.9.2021.

26 Na sua Primeira Sustentação Oral: "O representante do Ministério Público Federal, Waldir Alves, apresentou manifestação reiterando as conclusões do parecer ministerial anteriormente lançado no processo" (174ạ Sessão Ordinária, de 31.3.2021). Enquanto na Segunda Sustentação Oral: "Na presente sessão o representante do Ministério Público Federal, Waldir Alves, fez uso da palavra para esclarecer a posição do MPF acerca do caso concreto, pela reiteração da decisão da Superintendência-Geral de não instauração de processo administrativo, diante da insubsistência de indícios de infração da ordem econômica e que, no toca ao processo em análise, não houve o efetivo cumprimento das obrigações assumidas pelas signatária do acordo celebrado com o Cade, bem como que seja mantido o sigilo da identidade dos signatários, do histórico da conduta e dos documentos trazidos aos autos pelos signatários, nos termos da recomendação constante no Parecer no 5/2017/PFE-Cade, e a imposição de impedimento de celebrar novo acordo de leniência com o Cade pelo prazo de três anos." (175 a Sessão Ordinária, de 14.4.2021).

27 “O Conselheiro Relator proferiu voto pela declaração de descumprimento do Acordo de Leniência no 02/2018, diante da inexistência dos resultados previstos nos incisos I e II do caput do art. 86 da Lei no 12.529/2011, e do descumprimento dos subitens 4.1, 4.2, 4.3 e 4.6 da cláusula quarta do Acordo, com a constituição do impedimento para celebrar novo acordo de leniência com o Cade pelo prazo de três anos, contado da data deste julgamento, nos termos do §12 do art. 86 da Lei no 12.529/2011; bem como pela expedição de ofício com cópia da decisão e manutenção da confidencialidade da identidade dos signatários, do histórico da conduta e dos documentos trazidos aos autos pelos signatários, nos termos da recomendação constante no Parecer no 5/2017/PFE-Cade." (174a Sessão Ordinária, de 31.3.2021). 
14.4.2021 ${ }^{28}$ ), em voto divergente, a Conselheira Lenisa Rodrigues Prado homologou o Acordo de Leniência, no que foi acompanhada pelo Conselheiro Luiz Hoffmann, que acresceu ao seu voto a manutenção da confidencialidade da identidade dos Signatários e o acesso restrito ao Histórico da Conduta e documentos trazidos aos autos (nos termos da recomendação do Parecer no 5/2017/PFE-Cade), sendo este último acompanhado pelo Conselheiro Mauricio Oscar Bandeira Maia. O Conselheiro Luis Henrique Bertolino Braido proferiu voto no sentido do parecer do Ministério Público Federal junto ao Cade, e acompanhou o voto do Conselheiro Relator Sérgio Costa Ravagnani, reconhecendo a impossibilidade de declaração de cumprimento de Acordo de Leniência quando o material fornecido pelo leniente não propiciou a realização de medidas investigativas eficazes, como o requerimento de medida cautelar ou busca e apreensão, tratando-se de material imprestável à investigação, por isso não cumprido o acordo. A Conselheira Lenisa Prado incorporou em seu voto a proposta de dispositivo trazida pelo Conselheiro Luiz Hoffmann, e nessa extensão foi acompanhada pela Conselheira Paula Azevedo e pelo Presidente Alexandre Barreto de Souza.

Há, consequentemente, espaço para o debate acerca do controle da eficácia dos acordos de leniência pelo Tribunal do Cade, e dos critérios objetivos que orbitam os conceitos de efetividade da colaboração e do resultado útil do processo tal qual previsto pela norma.

\section{CONSIDERAÇÕES FINAIS}

Sendo o acordo de leniência antitruste um dos principais instrumentos de descoberta e revelação de infrações contra a Ordem Econômica, notadamente, de cartéis, que constituem a mais grave espécie de violação ao sistema, e por tratar-se de um verdadeiro negócio jurídico consensual, que pressupõe espontaneidade, voluntariedade e boa-fé, a concessão dos benefícios premiais pelo Estado está necessariamente condicionada ao efetivo adimplemento das obrigações assumidas pelo signatário no acordo de leniência pactuado, sem, contudo, descuidar-se dos resultados legais indicados pela norma.

É importante a preocupação e a cautela com a análise e mensuração da ação colaborativa, compreendida objetivamente a partir dos critérios previstos legalmente e, principalmente, com o resultado útil do processo, a partir de dados concretos, e da realização de controle da eficácia dos acordos pelo Tribunal Administrativo do Cade. Faz-se necessário avaliar se os termos e as obrigações do acordo de leniência foram cumpridos, bem como se os resultados concretos foram atingidos, tal qual previsto no artigo 86 da Lei no $12.529 / 2011$.

28 “A Conselheira Lenisa Prado apresentou voto vista pela homologação do Acordo de Leniência. O Conselheiro Luiz Hoffmann acompanhou o voto da Conselheira Lenisa Prado, com proposta de que seja declarado o cumprimento do Acordo de Leniência no 02/2018, com determinação de: (i) decretação da extinção da ação punitiva da Administração Pública em favor dos infratores signatários, nos termos do art. 86, § 40-, I da Lei 12.529/2011; (ii) expedição de ofício ao Ministério Público Federal no Distrito Federal (8o Oficio de Combate ao Crime e à improbidade Administrava), com cópia da presente decisão; e (iii) manutenção da confidencialidade da identidade dos Signatários, bem como do acesso restrito ao histórico da conduta e documentos trazidos aos autos pelos Signatários, nos termos da recomendação constante no Parecer no 5/2017/PFECade. 0 Conselheiro Luis Braido aderiu às conclusões do Conselheiro Relator. O Conselheiro Mauricio Oscar Bandeira Maia acompanhou o voto do Conselheiro Luiz Hoffmann. A Conselheira Lenisa Prado manifestou-se informando a incorporação, em seu voto, da proposta de dispositivo trazida pelo Conselheiro Luiz Hoffmann. A Conselheira Paula Azevedo e o Presidente do Cade acompanharam o voto da Conselheira Lenisa Prado com a incorporação do dispositivo trazido pelo Conselheiro Luiz Hoffmann." (175a Sessão Ordinária, de 14.4.2021). 
Conceitos como utilidade, resultado e eficácia devem ser vistos como a tônica da colaboração, revelando que esta não é um fim em sim mesmo, mas um meio que inclui, necessariamente, como previsto em lei, a identificação dos demais envolvidos na infração e o fornecimento de informações, documentos e elementos que comprovem minimamente a infração relatada ou que indiquem à autoridade onde essas provas podem ser obtidas, fornecendo o fumus boni iuris para uma diligência investigativa eficaz.

Raciocínio diverso esvaziaria o conteúdo legal da efetividade da colaboração e do resultado útil do processo, previsto no artigo 86 da Lei no 12.529/2011, como também o próprio interesse público inerente aos acordos de leniência, cuja decisão final de declaração de seu descumprimento a partir da constatação da ineficácia da colaboração, quando comprovado o não atendimento das obrigações assumidas, a despeito de não ser desejada e de trazer consequências ao signatário, aponta ser a postura adequada nessas situações.

O não reconhecimento do cumprimento do acordo também fixa efeitos pedagógicos e reflexos no Sistema Brasileiro de Defesa da Concorrência (SBDC), contribuindo para a solidificação do real significado do agente colaborador e da utilidade dos acordos de leniência, evitando-se a frustração da expectativa gerada, além da posição prioritária conferida ao signatário para assinar o acordo antes dos demais investigados e partícipes do ilícito, e com isso receber os melhores beneficios.

Tais fatos evidenciam a importância das obrigações assumidas pelo signatário no acordo e a relevante e exclusiva competência atribuída ao Tribunal Administrativo do Cade para declarar o cumprimento ou o descumprimento dos acordos de leniência, realizando um verdadeiro controle de sua eficácia, tanto sob o aspecto formal como material, compreendido na verificação do cumprimento do pactuado na Superintendência-Geral do Cade.

\section{REFERÊNCIAS BIBLIOGRÁFICAS}

ATHAYDE, Amanda. Manual dos Acordos de Leniência no Brasil: Teoria e Prática - Cade, BC, CVM, CGU, AGU, TCU, MP. Belo Horizonte: Fórum, 2019.

BRASIL. Constituição da República Federativa do Brasil de 1988. Brasília: Presidência da República, 1988.

BRASIL. Lei no 8.137, de 27 de dezembro de 1990. Define crimes contra a ordem tributária, econômica e contra as relações de consumo, e dá outras providências. Brasília: Presidência da República, 1990.

BRASIL. Lei no 8.884, de 11 de junho de 1994. Transforma o Conselho Administrativo de Defesa Econômica (Cade) em Autarquia, dispõe sobre a prevenção e a repressão às infrações contra a ordem econômica e dá outras providências. Brasília: Presidência da República, 1994.

BRASIL. Lei no 12.529, de 30 de novembro de 2011. Estrutura o Sistema Brasileiro de Defesa da Concorrência [...] e dá outras providências. Brasília: Presidência da República, 2011.

BRASIL. Lei no 12.850, de 02 de agosto de 2013. Define organização criminosa e dispõe sobre a investigação criminal [...]. Brasília: Presidência da República, 2013.

BRASIL. Lei no 13.964, de 24 de dezembro de 2019. Aperfeiçoa a legislação penal e processual penal. 
Brasília: Presidência da República, 2019.

BRASIL. Conselho Administrativo de Defesa Econômica. Guia do Programa de Leniência Antitruste do Cade. Brasília: Cade, 2016. Disponível em: https://www.gov.br/cade/pt-br/assuntos/programa-de-leniencia/guia-do-programa/guia-do-programa-de-leniencia. Acesso em 17 fev. 2021.

BRASIL. Conselho Administrativo de Defesa Econômica. Processo Administrativo no 08700.008004/2017-15. Relator: Conselheiro Paulo Burnier da Silveira, 2017. Disponível em: https:// sei.cade.gov.br/sei/modulos/pesquisa/md_pesq_documento_consulta_externa.php?DZ2uWeaYicbuRZEFhBt-n3BfPLlu9u7akQAh8mpB9yM8F6yjHH5SHCA8ZdCTT9uLeaJ04BHkLl40kwzrl3VGOtk4vmtCM7EjbVX5nl8xle2RdSs_5DolGD8IKh3Y3F5x. Acesso em: 23 set. 2021.

BRASIL. Conselho Administrativo de Defesa Econômica. Processo Administrativo no 08700.008005/2017-51. Relator: Conselheiro João Paulo de Resende, 2017. Disponível em: https://sei. cade.gov.br/sei/modulos/pesquisa/md_pesq_documento_consulta_externa.php?DZ2uWeaYicbuRZEFhBt-n3BfPLlu9u7akQAh8mpB9yNFesGYSvMK3yHDhrYRoYoT6sBtlxuJeOfOyEyL5cecLBZkZi-t-fZlaSOeTDttSkgn5jZ6gkG06smdMSjlQ8I4. Acesso em: 23 set. 2021.

BRASIL. Conselho Administrativo de Defesa Econômica.Processo Administrativono08700.010320/201234. Relatora: Conselheira Polyanna Ferreira Silva Vilanova, 10.7.2019. Disponivel em: https://sei.cade. gov.br/sei/modulos/pesquisa/md_pesq_documento_consulta_externa.php?DZ2uWeaYicbuRZEFhBt-n3BfPLlu9u7akQAh8mpB9yNh-F4J0xzXiwr81vbfOy7NeuwOqAdDapxK0afgQpY5ksjGNJVw5X1X_5_ eVBU8EvLBaifRvicok203LN7DnE9m. Acesso em: 23 set. 2021.

BRASIL.ConselhoAdministrativo de Defesa Econômica. InquéritoAdministrativono08700.003246/201712. Relator: Conselheiro Sérgio Costa Ravagnani, 31 de março de 2021. Disponivel em: https://www. gov.br/cade/pt-br/assuntos/sessoes/2021/174a-sessao-ordinaria; https://www.gov.br/cade/pt-br/ assuntos/sessoes/2021/175a-sessao-ordinaria; Acesso em: 23 set. 2021.

BRASIL. Conselho Administrativo de Defesa Econômica. Regimento Interno do Cade. Brasília: Cade, 2020. Disponivel em: https://cdn.cade.gov.br/Portal/centrais-de-conteudo/regimento-interno/Regimento-interno-Cade-versao-05-2021.pdf. Acesso em: 23 set. 2021.

BRASIL. Ministério Público Federal (5. Câmara de Coordenação e Revisão - Combate à Corrupção). Nota Técnica no 01/2017. Brasília: 2017. Disponível em: http://www.mpf.mp.br/atuacao-tematica/ ccr5/notas-tecnicas/docs/nt-01-2017-5ccr-acordo-de-leniencia-comissao-leniencia.pdf. Acesso em: 2 mar. 2021.

BRASIL. Supremo Tribunal Federal. Petição 7.074 Q0/DF - Distrito Federal. Relator: Min. Edson Fachin, 3 de maio de 2018. Disponivel em: https://jurisprudencia.stf.jus.br/pages/search/sjur384341/false. Acesso em: 2 mar. 2021.

DIDIER JR., Fredie; BOMFIM, Daniela Santos. A colaboração premiada como negócio jurídico processual atípico nas demandas de improbidade administrativa. A\&C -Revista de Direito Administrativo e Constitucional, Belo Horizonte: Fórum, v. 17, no 67, jan./mar. 2017.

FORGIONI, Paula A. Os Fundamentos do Antitruste. São Paulo: Revista dos Tribunais, 2016.

FRANCESCHINI, José Inácio Gonzaga; BAGNOLI, Vicente. Direito Concorrencial, V. II. Coleção Tratado de Direito Empresarial. 2. ed. São Paulo: Thomson Reuters Brasil, 2018. 
GABAN, Eduardo; DOMINGUES, Juliana Oliveira. Direito Antitruste. 4. ed. São Paulo: Saraiva, 2016. LIMA. Márcio Barra. A atuação do Ministério Público Federal junto ao Cade. Revista Defesa da Concorrência, Brasília, v. 6, n 1, p. 5-23, maio 2018.

MARRARA, Thiago. Acordos no Direito da Concorrência. Revista da Defesa da Concorrência, Brasília, v. 8, n 2, p. 78-103, dez. 2020.

MARTINEZ, Ana Paula. Repressão a Cartéis: Interface entre Direito Administrativo e Direito Penal. São Paulo: Singular, 2013.

MIRANDA, Francisco Cavalcanti Pontes de. Tratado de direito privado. 2. ed. atual. por Vilson Rodrigues Alves. Campinas: Bookseller, t. 1, 2000.

ORGANIZAÇÃO PARA A COOPERAÇÃO E DESENVOLVIMENTO ECONÔMICO (OCDE); BANCO INTERAMERICANO DE DESENVOLVIMENTO (BID). Lei e Política da Concorrência no Brasil: Uma Revisão pelos Pares. 2010. p. 43. Disponivel em: http://www.oecd.org/daf/competition/45154401.pdf. Acesso em: 8 mar 2021.

Lei e Política da Concorrência no Brasil: Uma Revisão pelos Pares. 2005. p. 48. Disponível em: http://www.oecd.org/brazil/35684126.pdf. Acesso em: 8 mar 2021.

PETTER, Lafayete Josué. Direito Econômico. 4. ed. Porto Alegra: Verbo Jurídico, 2009.

PIMENTA, Raquel de Mattos. A construção dos Acordos de Leniência na Lei Anticorrupção. Editora Blucher: São Paulo, 2020.

TAUFICK, Roberto Domingos. Nova Lei Antitruste Brasileira: Avaliação Crítica, Jurisprudência, Doutrina e Estudo Comparado. São Paulo: Almedina, 2017. 